\title{
Application in China of human resource accounting
}

\author{
${ }^{1, a}$ Mengfei Xiang \\ ${ }^{1}$ College of Economics \& Management, China Three Gorges University, Yichang city, China, \\ 443000 \\ a65093882@qq.com
}

\begin{abstract}
Keywords: Accounting measurement; Human resources; Human resource accounting; Human Capital
\end{abstract}

\begin{abstract}
The 21st century is the era of knowledge economy, Competition among enterprises has been the natural resources and capital competition to the competition of talents, knowledge and talent as a powerful force for social development and its importance is more and more attention. Human resource accounting in the use of economics, organizational behavior based on the principle of mutual infiltration, mutual combination, a special kind of accounting discipline formed and human resource management, is a procedure and method to measure and report the cost and value of human resources to the organization, is a new field of accounting discipline development. In this context of human resource accounting as a new branch of accounting emerged. China currently accounting for the Study of Human Resources to explore the application of human resource accounting situation in China, analyze difficulties and problems studied its existence and provide some solutions to the further development of China-based human resource accounting.
\end{abstract}

\section{Introduction}

The 21 st century is the era of knowledge economy, science and technology are rapidly advancing global wave of positive corporate survival and development of the center of gravity by tilting the competition to compete for resources and capital to knowledge, technology and talents. Stimulating economic growth in the traditional horse-drawn carriage by the violent impact of the knowledge economy, the role of knowledge and technology to promote the business forward as a great power whose core competence is increasingly clear that companies are concerned about the human resource information in its possession and to it included corporate strategic management, accounting also experiencing this doctrine from the object to the people-oriented reform process. In this context, the emerging field of human resource accounting as the accounting discipline applied accounting practitioners is increasing. Human resource accounting to corporate human resources for the study, reflecting the economic benefits of corporate human resources and related information and pass it to business managers, human resource management decisions and provide effective and reliable basis for enterprise information users. Therefore, vigorously carry out accounting human resource accounting has very real sense.

In this paper, a review of the relevant literature and human resources combined with previous studies, systematically expounded the theory of human resource accounting, and human resources management situation in China combined with the analysis, discusses the plight of Chinese human resource accounting and related issues arise, and try to find some good the proposal countermeasures to promote China's human resource accounting forward the further development of human resource accounting to provide new ideas.

\section{HUMAN RESOURCE ACCOUNTING CONCEPTS AND THEORIES}

Human Resources:Generalized on human resources broadly defined called labor resources. It is to be able to promote the economic and social development, with the total working population. The basic human resources include four aspects of physique, intelligence, knowledge and skills. Human Resources in the narrow sense refers to the company's internal staff can create profit and value (from 
management to general staff) for enterprises of all knowledge, abilities, skills sum, this paper discuss human resource accounting is such a narrow focus human resources.

Human Assets:Human assets is a human resource, it bears a possible future earnings, with future profitability, is a special asset of enterprises. The characteristics of human assets have general assets. First, companies have control over them, that term labor contracts for workers within the enterprise knowledge, abilities and skills have obtained exclusive rights; secondly human assets are able to bring economic benefits to the enterprise resources, corporate human assets acquired the purpose is to obtain economic benefits; third, human assets, while not having the physical form, but you can use monetary measures, similar intangible assets; Finally, human assets with high liquidity and uncertainty, human assets can not always is owned enterprises.

Human Resource Accounting Concepts:Human Resource Accounting is a method of accounting recognition and measurement of corporate human resources, the purpose is to provide information on corporate human resource data to the enterprise information needs to use. The subject of human resource accounting is required to use the human resources information accounting units of the organization, including national, enterprises and units; object is the cost and value of human resources; accounting method is used accounting methods to reflect the accounting records of human resources through information situation; aim is to provide reliable information for the management of human resources information to help users make the right decisions.

Human Resource Accounting Theory:(A) Human capital theory. Land is the mother of wealth and labor is the father of wealth. Is a special kind of human resources, and is a special initiative of the resource has. Human capital (Human Capital Management) theory originated in the 1960s, American economist Schultz and Becker founded the human capital theory. The theory is that physical capital refers to capital goods on the matter, including plant, equipment, materials, land, money, etc.; human capital is reflected in the workers' capital, that for workers education, training and other expenses, the specific performance of the sum of all kinds of knowledge and skills for workers has. In the human capital theory, human capital and physical capital are separate, because of their different essence. This breakthrough in fundamental accounting theory is the view of the capital only physical capital. The status of human capital in the enterprise is more and more apparent. And its uniqueness is more and more important. The concept of human resource accounting in human capital and human assets are also based in the formation of human capital theory.

(B) People management theory [4]. People management theory emphasizes the "people-oriented" management model. Material resources and capital are not considered the company's most important resource is the core competitiveness of enterprise development staff, so companies should also attach importance to the management of human resources management business. Enterprises should reasonably apply scientific methods to manage employee, employee-centric establishment of corporate culture; staff to try to meet their own quality improvement and self-realization needs, so as to allow each employee to maximize their own initiative in order to improve efficiency and achieve maximize enterprise value. Made of human resources, maintenance and other aspects of human resources information should be timely disclosure of accounting information in the show, behavioral aspects of human resources information, although not monetization but also should be disclosed. From the point of view, people management theory for the development of human resource accounting undoubtedly played a significant role in promoting.

\section{APPLICATION STATUS AND PROBLEMS OF HUMAN RESOURCE ACCOUNTING CHINA}

Classification:An important role of human resources in the enterprise is obvious, but the development of human resource accounting has not kept pace for a while with HUAWEI, Huayi Bros. Media Group and other talent as the core competitiveness of large enterprises has grown from human resource accounting these aspects make the attempt, but China does not have a full implementation of the human resources and accounting management of the enterprise. The paper combined with the related data. The current situation of human resource accounting for China enterprises to implement the classification, generally divided into three categories. 
Human Resource Accounting Measurement is not Carry Out:Human Resource Accounting Human Resources including obtaining human resources, maintenance, deployment and other costs, and for the vast majority of enterprises, the majority of these costs in addition to other salary bonuses are classified into various other costs go up, and no special imputation into a special account belonging to human resources, which led to the financial statements, we usually only see some executives salary, but also human resources only quantitative data tracked, quantified measurement of human resource accounting Lack bound to affect the validity of financial reporting.

Human Resources not be Measure as an Asset:At present China enterprise fails to human resources as a separate asset confirmation and measurement. Chinese accounting theory academia lack of unified study on human resources, related accounting standards on the human resources did not develop, the related information of human resources is not reported in the financial statements, only some salary, training costs and other expenses expenditure, not be capitalized. This and the requirement of accounting information is clearly not consistent.

Human resources information disclosure is not complete full:At present, the accounting fields are uneven about the application of human resources accounting. Although there are some good companies know the importance of human resource accounting but subject to national human resources for the development of uniform accounting standards and can not further develop human resource accounting; some companies have only a simple disclosure, a considerable part of the enterprise or not disclosure of information on human resources. Most of the contents of the disclosure of the same basic situation is nothing more than the number of executives and staff salaries, education, etc., and disclose the contents differ. But this situation gradually improved each year. Overall, do human resource accounting business on the rise, the relevant disclosure of information on human resources is also the same increase, which we should appreciate that.

Human Resources is Difficult to Confirm the Project as an Asset: Whether human resources meet the definition of assets and accounted for as an asset, accounting experts who have different opinions and differences. A view that does not match the definition of human resources and assets can not be accounted for as an asset; others are thought to play ever since it entered the corporate human resources the moment for business owners to control and create value for the enterprise to bring economic benefits will flow, and therefore can be accounted for as an asset. These two different views make accounting human resources accounting is not smooth progress, which directly led to the difficulties of human resources in accounting confirmation.

Human resource accounting is difficult to accurately measure:How human resource to fair, accurate measurement has always been a huge human resource accounting hinder further development forward. Human resources exist in the measurement of the confirmation process greater subjectivity, uncertainty [6]. There is no agreed standard to standardize the measurement of human resources. Accounting scholars have also raised many measurement methods, but each method inevitably limitations. Human resource costs have historical cost measurement methods, realistic replacement cost method and opportunity cost method. Cost of human resources development, although relatively simple, but the Human Resource Evaluation go awry; realistic replacement cost method increases the workload and assessment with a strong subjective; accounting of the amount of opportunity cost is large, only a small scope applies to some key positions, it is difficult to promote. So far there is no accounting academics to form a unified standards and guidelines to regulate the human resource accounting, which greatly hinder human resource accounting application in the enterprise.

Equity Allocation of Human Resource Accounting is not clear:According to human capital theory, corporate resources into human resources and material resources, and the economic interests of the enterprise by enterprise resource created, see how economic interests in both the rational allocation of resources has been inconclusive. Increasing share of human resources, contribution to the business is also growing, once the allocation is unreasonable if it is possible to dampen the enthusiasm of employees. To motivate employees, many companies have introduced incentives ESOP, stock options, etc., but after all, is the real foundation of economic ownership interest in the material and human resources between the rational allocation should be to achieve a reasonable 
distribution through pricing. Since the definition of property rights is not clear, measurement of human resources there is a certain bias. How human resource allocation problem in income, also known as the development of human resource accounting stumbling block.

Human Resource Accounting Information Disclosure:Under China's current accounting system, corporate accounting reports including balance sheet, income statement, cash flow statement, changes in equity and statements. Even in the case of Chinese accounting standards with international accounting standards convergence of Chinese accounting statements still no information on the human resources information disclosure requirements, the only way to reflect the human resources information is payable in the balance sheet of a payroll, most companies almost human Resources did not recognized as a separate one. Financial reporting that lack of human resources information disclosure obviously does not meet the current requirements of modern accounting. We should gradually increase the disclosure of the extent of human resource accounting information.

\section{PROMOTR OF THE DEVELOPMENT OF CHINA'S HUMAN RESOURCE ACCOUNTING APPLICATION COUNTERMEASURES}

To Increase the Theoretical Study of Accounting:Human resource accounting profession application in practice very little of which is a very important reason is difficult to confirm in human resource accounting, and the root of human resources accounting is difficult to confirm the lack of a complete set of Chinese human resource accounting theory currently systems. At present, most of China on human resource accounting theory comes mostly translated from foreign literature, there are few original, a lot of rote theory does not meet China's national conditions, difficult to apply to Chinese accounting practitioners. So you want to further develop human resource accounting theory research must increase accounting, establish a set of human resource accounting in line with the theory of China's socialist market economic system of the National Day.

Improvement of Human Resource Accounting Measurement Methods:Value of human resources is difficult to separate the accurate measurement of monetary estimate, we can consider while using non-monetary measurement methods to measure, the measurement of monetary and non-monetary measures combine more persuasive. For non-important general human assets can be used historical cost method of accounting of its value to the enterprise spent recruiting and training expenditures and other accounting basis. For important core enterprise human resources should be devoted by the enterprise valuation. When was defined as an important human assets, the credited human capital projects. According to the assessed value, debit note "human assets" (when acquired), credit note "human capital"; view of human assets and intangible assets have some similarities, you can get inspiration from the accounting treatment of intangible assets, human assets will investment as companies get a special intangible assets related to the accounting treatment can also refer to the accounting treatment of intangible assets.

The Financial Statements Presented Human Resource Information:If the human resource-related information is not presented in the financial statements, the Company's financial statements will be distorted. It is difficult to reflect the true. Human resource information has great impact on the earnings information users, we should prepare its financial statements contain human capital. On the balance sheet can refer to additional intangible "human assets", "human assets amortization", "human assets net" and other subjects. In the report notes, companies should disclose their focus on core technical staff and executives of information, so that we can clear understanding of corporate management level of education, history and other information that can help us predict the future prospects of the enterprise in order to make investment decision making. As for the general staff of enterprises, for the disclosure of cost considerations, you can focus on the disclosure of their education, age and skill level and other information.

mproving human resource accounting standards and systems: A more important reason why China can not advance human resource accounting run in circles its accounting practices related laws and regulations are not sound enough, only in the relevant policies and laws are more perfect, human resource accounting can be well implemented. Double protection good institutional environment and a sound legal environment is the development of human resource accounting standards, the 
establishment of a sound human resources to ensure that the relevant laws and regulations. At the same time companies need to have a sound labor contract system, to ensure the stability of human resources transactions, reduce transaction costs, so as to guarantee the normal functioning of human resource accounting.

\section{CONCLUSION AND OUTLOOK}

With the advent of the era of knowledge economy, human resource accounting and more attention and develop into a new branch of theoretical and practical significance are extremely important to modern accounting, but China's current human resource accounting theory is still in a facile stage application in practice is not very in-depth sector, there needs to be further development and improvement.

Firstly, the theory of human resource accounting, combining the current situation of China human resource development in-depth analysis of accounting problems and gives some improvements.

As a product of the modern knowledge-based economy, human resources, accounting practitioners, although currently in the application there are still many difficulties, but we believe that with the

Chinese market, the deepening of economic reform, and constantly improve the social laws and regulations, and the prospects for development of human resource accounting must be very broad, further application of human resource accounting will be realized in China.

\section{References}

[1] Eric.G.Flamholts. Human Resources Accounting Management. [M] Shanghai Translation Publishing House.1986

[2] Zhongwen Liu. Human Resources Accounting [M].Beijing: Capital University of Economics and Business Press.1997.

[3] Xingqiang Du. Human Resources Accounting Recognition, Measurement and Report [J]. Accounting Research.1997,(12).

[4] Zhongwen Liu. Research on Human Resource Accounting[M]. Beijing: Chinese financial \& Economic Publishing,2006:1

[5] Dawu Yan. A Framework of Human Resource Accounting[J]. Accounting Research,1996(11)

[6] Daxian Liu. Several Problems Existing in The Current Research on Human Resource Accounting[J]. Accounting Research.1999(7) 